\title{
A multi-criteria assessment of relative farming efficiency in the European Union Member States
}

\author{
Tomas Baležentis \\ Lithuanian Institute of Agrarian Economics, \\ V. Kudirka Str. 18, LT-03105 Vilnius \\ E-mail: tomas@laei.lt
}

\author{
Alvydas Baležentis \\ Mykolas Romeris University, \\ Valakupiai Str. 5, LT-10101 Vilnius \\ E-mail:a.balezentis@gmail.com
}

\begin{abstract}
The assessment of economic sector efficiency is of high importance when making strategic decisions at any management level. This study, hence, is aimed at proposing a new framework for multi-criteria assessment and comparison of farming efficiency. In order to achieve this aim, statistical analysis, the multi-criteria decision-making method MULTIMOORA, and data envelopment analysis were employed. Farming efficiency was evaluated across the EU Member States on the basis of data from the Farm Accountancy Data Network. The proposed indicator system covers the three ratios, which virtually describe the other six input or output indicators. The EU Member States were ranked according to the indicator system by the MULTIMOORA method. The application of DEA enabled to identify the main factors of inefficiency. Attention was focused on the three Baltic States and Poland. The analysis suggests that farming efficiency in these states is below the EU average. More specifically, land productivity should be increased in the Baltic States. Moreover, the increased crop output would enable to achieve the efficiency frontier. The future challenges for the agricultural development of the Baltic States are discussed in the paper.
\end{abstract}

Key words: farming efficiency, multi-criteria decision making, data envelopment analysis, strategic management

\section{INTRODUCTION}

Assessment of the efficiency of a certain economic sector is of high importance when making strategic decisions at any management level. Furthermore, increase in efficiency leads to an increase in the competitiveness of production. It is the Common Agricultural Policy and Single Area Payments of the European Union (EU) that involve the EU Member States and their agricultural sectors into the processes of competition, convergence and cohesion. The competitiveness of the Lithuanian agricultural sector, hence, becomes an even more actual issue. Moreover, given the relatively high share of the gross value-added generated in the primary sector, peculiar to the Central and Eastern European states, agricultural efficiency is of crucial importance here (Gorton, Davidova, 2004).

Hence, a number of studies have attempted to investigate the issues of efficiency and competitiveness. Indeed, data envelopment analysis (DEA) is a method widely applied for efficiency assessment (Odeck, 2009; Vinciūnienè, Rauluškevičienè, 2009). Gorton and Davidova (2004) provided an overview of papers on farm productivity and efficiency. Kriščiukaitienè et al. (2007) and Tamošaitienè et al. (2010) have analysed the efficiency of Lithuanian farms. A multi- dimensional comparison of Lithuanian farm efficiency was performed by Baležentis and Baležentis (2011a). Although Baležentis and Baležentis (2010) have performed an international comparison of the EU Member States' achievements in rural development, there is a lack of such comparison in the farming efficiency area. The study of Rimkuviene et al. (2010) is the only Lithuanian contribution to the area under discussion.

The aim of this study is to identify the prospective development directions of the Lithuanian agricultural sector by proposing a new framework for a multi-criteria assessment and comparison of farming efficiency. Consequently, such an assessment can constitute a basis for strategic decision support. The efficiency of farming will be evaluated by applying the multi-criteria decision-making (MCDM) method MULTIMOORA (Multi-Objective Optimization plus the Full Multiplicative Form) as well as DEA.

Noteworthy are some innovative features of this study. The derived economic indicators, namely ratios, are used as the variables to evaluate farming efficiency, instead of the typically used input-output variables. Another important feature is the absence of inputs in the DEA model which, while not innovative, is relatively underutilized. In this study, performance is measured with an output vector consisting of three ratios 
and no inputs. Such a modelling constitutes an interesting alternative for efficiency evaluation and a complement to the simple ratio analysis employed by agricultural economists. Finally, the application of the MCMD method MULTIMOORA enables to validate the results obtained by DEA.

It is the complex nature of contemporary socio-economic phenomena that makes MCDM methods more and more actual nowadays (Kahraman, 2008; Zavadskas, Turskis, 2011). The expanding spectrum of multi-criteria problems encompasses both business and public sector decisionmaking and benchmarking. Indeed, Roy (1996) offers the following classification of MCDM problems: 1) choosing a problem - choosing the best alternative; 2 ) sorting a problem - classifying alternatives into relatively homogeneous groups; 3) ranking a problem - ranking alternatives from best to worst; 4) describing a problem - describing alternatives in terms of their peculiarities and features. In our study, we shall apply the MULTIMOORA method for the multicriteria assessment of farming efficiency in the EU Member States. This method was introduced and developed by Brauers and Zavadskas $(2006,2010 \mathrm{a})$. MULTIMOORA was applied in regional development studies (Brauers, Zavadskas, 2010b; Baležentis, Baležentis, 2011b). However, the MCDM method provides ranking without any additional information. The use of additional methods, therefore, becomes an actual issue.

The DEA method, however, is characterised by opposite characteristics. It is a nonparametric method of measuring the relative efficiency of a decision-making unit such as a firm or a public sector agency, which results in estimating their actual as well as potential efficiency. The ranking based on this efficiency is usually not very robust (Jaržemskiene, 2009). Nevertheless, DEA offers some additional information which soundly supports the multi-criteria optimization. DEA was first introduced by Charnes et al. (1978). It is a relative technical efficiency measurement tool which uses operation research techniques to automatically calculate the weight assigned to the input and output of the production units (Kahraman, 2008). Thus, neither market prices nor disaggregation of inputs and outputs are mandatory. Indeed, DEA was applied in studies of agriculture (Alvarez, Arias, 2004; Gorton, Davidova, 2004; Vinciūniené, Rauluškevičienė, 2009). The DEA ISYDS / SIAD package (Angulo Meza et al., 2005) will be applied in this study to evaluate the technical efficiency of farming.

The following tasks, therefore, are set: 1) to define an indicator set for estimating farming efficiency across the EU Member States; 2) to apply MULTIMOORA and DEA when estimating farming efficiency; 3) to check the consistency of results; and 4) to provide summarized guidelines for the future development.

The research was based on data provided by the Farm Accountancy Data Network (FADN). More specifically, the data cover the year 2008. The following methods were employed for the research: statistical analysis, the MCDM method MULTIMOORA, and DEA.

\section{METHODS}

The farming efficiency was evaluated across the EU Member States on the basis of data from FADN ${ }^{1}$. Noteworthy, FADN is an instrument for evaluating the income of agricultural holdings and might be used to study the impacts of the Common Agricultural Policy (CAP).

Accordingly, we established an indicator system identifying the main aspects of farming efficiency. The three ratios under consideration were derived by comparing the other six indicators identifying both inputs and outputs. A dimension reduction, thus, was achieved. The three ratios identify the productivity of the respective production factors and therefore should be maximized. As to the MCDM and DEA methods, the inputs should be minimized, whereas the outputs should be maximized. Table 1 summarizes initial data for 27 EU Member States.

The input indicators identify a bundle of material and financial resources - factors of production - employed in the production process. The total labour input expressed in AWU (annual work unit, i. e. full-time person equivalent) quantifies the labour input. The total Utilised Agricultural Area (UAA) in hectares resembles the land input. Total livestock units are converted into the so-called livestock units (LSU).

The output indicators describe the results of farming activities. Total outputs in Euro are estimated for crops and crop products, livestock and livestock products, etc. More specifically, we assess three derived ratios: the total crop output per ha, total livestock output per LSU, and the net value added expressed per agricultural work unit. The two former indicators enable to evaluate the productivity of land and husbandry. The indicator of farm net value added (in Euro) quantifies remuneration to the fixed factors of production (work, land and capital), whether they be external or family factors. In addition, labour productivity is assessed by considering farm net value added expressed per agricultural work unit. The pair-wise correlation coefficients among these three variables varied in the range 0.19 and 0.36 . Therefore, no serious multicollinearity existed in the data set.

Ranking according to MULTIMOORA. Belton and Stewart (2002) defined the three broad categories of MCDM methods: 1) value measurement models; 2) goal, aspiration, and reference level models; 3 ) outranking models (the French school). A more detailed overview of MCDM methods is presented by Zavadskas and Turskis (2011). In this study, we applied the MULTIMOORA method which encompasses the value measurement and reference level methods. The Multi-Objective Optimization by Ratio Analysis (MOORA) method was introduced by Brauers and Zavadskas (2006). This method was enhanced (Brauers, Zavadskas 2010a) and became a more robust method called MULTIMOORA (MOORA plus the full multiplicative form). These

1 FADN Public Database. Accessible on-line http://ec.europa.eu/agriculture/rica/database/database_en.cfm. 
Table 1. Initial data for assessing farming efficiency in the EU, 2008

\begin{tabular}{|c|c|c|c|}
\hline Country & Total crop output per UAA, EUR/ ha & $\begin{array}{c}\text { Total livestock output per LSU, } \\
\text { EUR / LSU }\end{array}$ & $\begin{array}{c}\text { Farm net value added per AWU, } \\
\text { EUR / AWU }\end{array}$ \\
\hline Belgium & 1722 & 1026 & 34262 \\
\hline Bulgaria & 593 & 721 & 4307 \\
\hline Cyprus & 1706 & 1774 & 9370 \\
\hline Czech Republic & 742 & 1034 & 14229 \\
\hline Denmark & 1278 & 1281 & 49973 \\
\hline Germany & 1076 & 1155 & 30171 \\
\hline Greece & 1979 & 996 & 11480 \\
\hline Spain & 937 & 764 & 22127 \\
\hline Estonia & 281 & 981 & 10485 \\
\hline France & 1043 & 928 & 29086 \\
\hline Hungary & 910 & 1192 & 15427 \\
\hline Ireland & 180 & 728 & 20646 \\
\hline Italy & 2414 & 1072 & 24389 \\
\hline Lithuania & 454 & 870 & 9904 \\
\hline Luxembourg & 539 & 1063 & 35361 \\
\hline Latvia & 343 & 937 & 7293 \\
\hline Malta & 7205 & 1072 & 13966 \\
\hline The Netherlands & 6132 & 1432 & 41762 \\
\hline Austria & 681 & 1382 & 26323 \\
\hline Poland & 791 & 1026 & 5661 \\
\hline Portugal & 521 & 771 & 8428 \\
\hline Romania & 687 & 654 & 8465 \\
\hline Finland & 616 & 1557 & 23127 \\
\hline Sweden & 687 & 1161 & 39629 \\
\hline Slovakia & 512 & 899 & 7872 \\
\hline Slovenia & 1014 & 767 & 3967 \\
\hline United Kingdom & 637 & 860 & 37366 \\
\hline EU-27 & 1050 & 994 & 17202 \\
\hline
\end{tabular}

methods have been applied in numerous studies (Brauers, Zavadskas, 2010b, 2011; Baležentis, Baležentis, 2010, 2011b) focused on regional studies, international comparisons and investment management.

The MOORA method begins with the matrix $X$ in which its elements $x_{i j}$ denote the $i$-th alternative of a $j$-th objective $(i=1,2, \ldots, m$ and $j=1,2, \ldots, n)$. In this case, we have $n=3$ objectives - input and output ratios - and $m=28$ alternatives - 27 EU Member States and the hypothetic EU average value. The MOORA method consists of two parts - the Ratio System and the Reference Point approach.

The Ratio System of MOORA (RS). The ratio system defines data normalization by comparing the alternative of an objective with all values of the objective:

$$
x_{i j}^{*}=\frac{x_{i j}}{\sqrt{\sum_{i=1}^{m} x_{i j}^{2}}},
$$

where $x_{i j}^{*}$ denotes the $i$-th alternative of the $j$-th objective (in this case the $j$-th structural indicator of the $i$-th state). Usually, these numbers belong to the interval [-1-1]. These indicators are added (if the desirable value of the indicator is maximum) or subtracted (if the desirable value is minimum), and the summary index of state is derived in the following way:

$$
y_{i}^{*}=\sum_{j=1}^{g} x_{i j}^{*}-\sum_{j=g+1}^{n} x_{i j}^{*},
$$

where $g=1, \ldots$, and $n$ denotes the number of objectives to be maximized. Then, every ratio is given the rank: the higher the index, the higher the rank.

The Reference Point of MOORA (RP). The reference point approach is based on the ratio system. The Maximal Objective Reference Point (vector) is found according to ratios found in formula (1). The $j$-th coordinate of the reference point can be described as $r_{j=\max } x_{j}^{*}$ in case of maximization. Every coordinate of this vector represents the maximum or minimum of a certain objective (indicator). Then, each element of the normalized response matrix is recalculated, and the final rank is given according to deviation from the reference point and the Min-Max Metric of Tchebycheff:

$$
\min \left(\max \left|r_{j}-x_{i j}^{*}\right|\right) \text {. }
$$

The Full Multiplicative form (MF) and MULTIMOORA. Brauers and Zavadskas (2010a: 13-14) proposed MOORA to be updated by the Full Multiplicative Form method 
embodying both the maximization and minimization of the purely multiplicative utility function. The overall utility of the $i$-th alternative can be expressed as a dimensionless number:

$$
U_{i}^{\prime}=\frac{A_{i}}{B_{i}},
$$

where $A_{i}=\prod_{j=1}^{g} x_{i j}, \quad i=1,2, \ldots, m$ denotes the product of objectives of the $i$-th alternative to be maximized with $g=1, \ldots, n$ being the number of objectives (indicators) to be maximized, and $B_{i}=\prod_{j=g+1}^{n} x_{i j}$ denotes the product of objectives of the $i$-th alternative to be minimized, with $n-g$ being the number of objectives (indicators) to be minimized. Thus, MULTIMOORA summarizes MOORA (i. e. the Ratio System and Reference point) and the Full Multiplicative Form. The three ranks provided by different parts of MULTIMOORA are summarized by applying the theory of dominance (Brauers, Zavadskas, 2011).

As one can see, the Reference Point prevents the MULTIMOORA from becoming a fully compensatory technique. Whereas the Ratio System and the Full Multiplicative Form are fully compensatory methods, the Reference Point is not. Indeed, the latter method is based on the Min-Max metric of Tchebycheff, which identifies certain alternatives characterized by a relative backwardness in either of criteria. Hence, the MULTIMOORA is quite an effective tool for assessing the sustainability of various phenomena resulting in an unbiased ranking of alternatives.

Data envelopment analysis. The data envelopment analysis (DEA) is a nonparametric method of measuring the efficiency of a decision-making unit (DMU) such as a firm or a public sector agency (Ray, 2004). The very term of efficiency was initially defined by Debreu (1951) and then by Koopmans (1951). It was Debreu who discussed the question of resource utilization at the aggregate level, whereas Koopmans offered the following definition of an efficient DMU: A DMU is fully efficient if and only if it is not possible to improve any input or output without worsening some other input or output. Due to similarity to the definition of the Pareto efficiency, the former is called the Pareto-Koopmans efficiency. Finally, Farrell (1957) summarized works of Debreu (1951) and Koopmans (1951): he offered the frontier analysis of efficiency and described two types of economic efficiency, namely technical efficiency and allocative efficien$c y$ (indeed, a different terminology was used at that time). The concept of technical efficiency is defined as the capacity and willingness to produce the maximum possible output from a given bundle of inputs and technology, whereas the allocative efficiency reflects the ability of a DMU to use the inputs in optimal proportions, considering respective marginal costs (Kalirajan, Shand, 2002). However, Farrell (1957) did not succeed in handling the Pareto-Koopmans efficiency with a proper mathematical framework.
The modern version of DEA was originated by A. Charnes, W. W. Cooper and E. Rhodes (Charnes et al., 1978; 1981). Hence, these DEA models are called CCR models. Initially, the fractional form of DEA was offered. However, this model was transformed into input- and output-oriented multiplier models which could be solved by means of linear programming (LP). In addition, the dual CCR model (i. e. envelopment program) can be described for each of the primal programs (Cooper et al., 2007; Ramanathan, 2003).

Unlike many traditional analysis tools, DEA does not require gathering information about the price of materials or produced goods, thus making it suitable for evaluating both private and public sector efficiency. Suppose that there are $j=1,2, \ldots, t, \ldots, N$ DMUs, each producing $r=1,2, \ldots, m$ outputs from $i=1,2, \ldots, n$ inputs. Hence, DMU $t$ exhibits the input-oriented technical efficiency $\theta_{t}$, whereas the output-oriented technical efficiency is a reciprocal number $\theta_{t}=1 / \phi_{t}$. The output-oriented technical efficiency $\phi_{t}$ may be obtained by solving the following multiplier DEA program:

$$
\begin{aligned}
& \max _{\varphi_{i} \lambda_{j}} \\
& \text { s.t. } \\
& \sum_{j=1}^{N} \lambda_{j} x_{i}^{j} \leq x_{i}^{t}, i=1,2, \ldots, n ; \\
& \sum_{j-1}^{N} \lambda_{j} y_{r}^{j} \leq \varphi_{t} y_{r}^{t}, r=1,2, \ldots, \\
& \lambda_{j} \geq 0, j=1,2, \ldots, N ; \\
& \varphi_{t} \text { unrestricted. }
\end{aligned}
$$

In Eq. (5), coefficients $\lambda_{j}$ are the weights of peer DMUs. Notably, this model presumes existing constant returns to scale (CRS), which is rather an arbitrary condition. CRS indicates that the manufacturer is able to scale the inputs and outputs linearly without increasing or decreasing the efficiency (Ramanathan, 2003).

Given that the CRS constraint was considered over-restrictive, the BCC (Banker, Charnes and Cooper) model was introduced (Banker et al., 1984). The CRS presumption was overridden by introducing a convexity constraint $\sum_{j=1}^{N} \lambda_{j}=1$, which enabled to tackle the variable returns to scale (VRS). The BCC model, hence, can be written as follows:

$$
\begin{aligned}
& \max _{\varphi_{i} \phi_{j}} \\
& \text { s.t. } \\
& \sum_{j=1}^{N} \lambda_{j} x_{i}^{j} \leq x_{i}^{t}, i=1,2, \ldots, n ; \\
& \sum_{j-1}^{N} \lambda_{j} y_{r}^{j} \leq \varphi_{t} y_{r}^{t}, r=1,2, \ldots, \\
& \sum_{j=1}^{N} \lambda_{j}=1 ; \\
& \lambda_{j} \geq 0, j=1,2, \ldots, N ; \\
& \varphi_{t} \text { unrestricted. }
\end{aligned}
$$


The best achievable input can therefore be calculated by multiplying the actual input by the technical efficiency of a certain DMU. On the other hand, the best achievable output is obtained by dividing the actual output by the same technical efficiency $\theta_{t}=1 / \phi_{t}$, where $\phi_{t}$ is obtained from Eq. (6). The difference between the actual output and the potential one is called a slack. In addition, it is possible to ascertain whether a DMU operates under increasing returns to scale (IRS), CRS, or decreasing returns to scale (DRS). CCR measures gross technical efficiency (TE) and hence resembles both TE and scale efficiency (SE), whereas BCC represents pure TE. As a result, pure SE can be obtained by dividing CCR TE by BCC TE. Interestingly, technical efficiency describes the efficiency by converting inputs to outputs, while scale efficiency recognizes that the economy of scale cannot be attained at all scales of production (Ramanathan, 2003).

A two-output example of an output-oriented DEA could be represented by a piece-wise linear production possibility curve, such as that depicted in Fig. 1. Note that the observations lie below this curve, and that the sections of the curve that are at right angles to the axes result in an output slack calculated when a production point is projected onto these parts of the curve by a radial expansion in outputs.

For example, point $P$ is projected to point $P^{\prime}$ which is on the frontier but not on the efficient frontier. This is because the production of $q_{1}$ could be increased by the amount $A P^{\prime}$ without using any more inputs. Thus, there is an output slack in this case of $A P^{\prime}$ in output $q_{1}$ (Coelli et al., 2005). The VRS (BCC) TE can be estimated as the $O P / O P^{\prime}$ ratio.

\section{RESULTS AND DISCUSSION}

As mentioned above, the efficiency of farming was assessed by applying the MCDM method MULTIMOORA and DEA. This section presents the results of these evaluations. Specifically, we shall pay particular attention to the three Baltic States, namely Estonia, Latvia, and Lithuania, as well as to Poland and Germany.

The application of MULTIMOORA begins with normalization of initial data (Table 1) by employing Eq. 1. Consequently, each Member State was attributed a respective ratio (Eq. 2) and thereafter ranked with respect to RS. Furthermore, Eq. 3 was applied in order to rank EU Member States according to RP. Finally, the states were ranked with respect to the MF approach (Eq. 4). These three ranks were summarized by applying the theory of dominance (Brauers, Zavadskas, 2011). The discussed data are provided in Table 2.

Initially, the EU Member States had been conditionally grouped into three groups, each of them encompassing high-, medium-, and low-performing states, respectively.

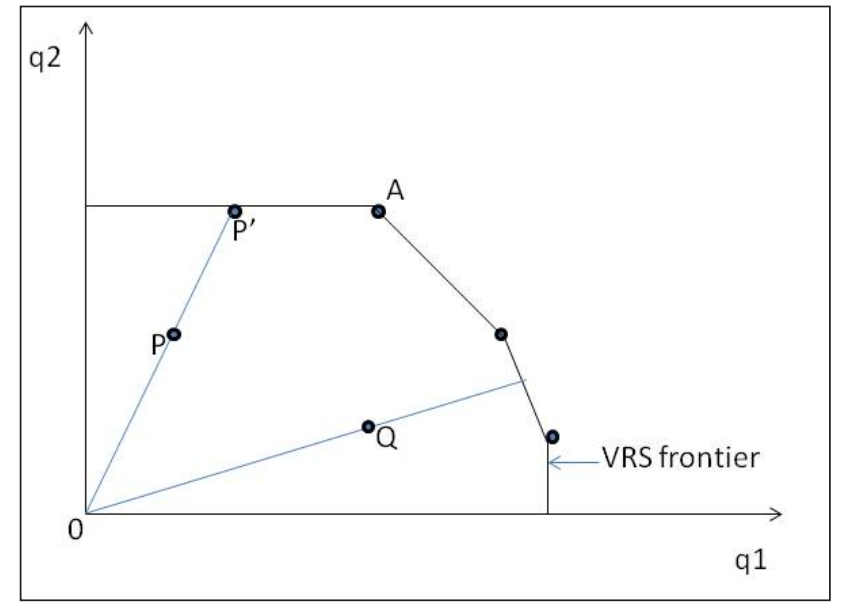

Fig. 1. Output-oriented DEA model

As one can see, the high-performance group consists of the Netherlands, Malta, Denmark, Italy, Belgium, Cyprus, Germany, Sweden, and France. Thus, the enumerated states can be considered as those characterized by the most relatively efficient farming practices. The underlying factors causing success of these states might be higher rates of CAP payments, a higher quality of agricultural land, and higher prices of agricultural production (Kriščiukaitienè et al., 2010a, 2010b).

The second group of states covers the EU average. More specifically, Austria, Greece, Finland, United Kingdom, and Luxembourg are characterized by a higher farming efficiency as compared with the EU average, whereas Hungary, Spain, Czech Republic, and Poland fall behind it.

The third group consists of Lithuania, Romania, Slovakia, Slovenia, Portugal, Estonia, Ireland, Latvia, and Bulgaria. With exceptions of Portugal and Ireland, this group encompasses the new EU Member States which are still undergoing transformations caused by the fall of the centrally planned economy. More specifically, the shortage of funds required for the modernization and labour-intensive mode of production prevents these states from gaining the competitive advantage.

Indeed, the old EU Member States (excluding Spain, Portugal, and Ireland) that had acceded the EU before 2004 were ranked above the EU average. The two small economies of Malta and Cyprus exhibited a relatively high efficiency. This phenomenon might be explained by a dynamic adjustment to market peculiar to such small-scale economies.

As one can see, Poland holds the rank of 19, whereas the Baltic States remain beneath. Lithuania (ranked 20th) is the first among its remaining Baltic neighbours, since Estonia and Latvia were attributed to ranks 25 and 27, respectively. Meanwhile, Latvia and Bulgaria were the last two states according to farming efficiency. The further analysis, namely the application of DEA, will explain the underlying reasons for inefficiency as well as prospective challenges to agricultural development in these states. 
Table 2. Ranking of the EU Member States by farming efficiency according to MULTIM00RA, 2008

\begin{tabular}{|c|c|c|c|c|c|c|c|}
\hline & \multicolumn{3}{|c|}{ Ratios } & \multicolumn{4}{|c|}{ Ranks } \\
\hline & RS & $\mathbf{R P}$ & MF & RS & RP & MF & Final \\
\hline The Netherlands & $3.7 \cdot 10^{11}$ & 1.150 & 0.099 & 1 & 1 & 1 & 1 \\
\hline Malta & $1.1 \cdot 10^{11}$ & 0.964 & 0.286 & 2 & 2 & 2 & 2 \\
\hline Denmark & $8.2 \cdot 10^{10}$ & 0.741 & 0.546 & 3 & 3 & 7 & 3 \\
\hline Italy & $6.3 \cdot 10^{10}$ & 0.606 & 0.441 & 4 & 5 & 3 & 4 \\
\hline Belgium & $6.1 \cdot 10^{10}$ & 0.612 & 0.505 & 5 & 4 & 5 & 5 \\
\hline Cyprus & $2.8 \cdot 10^{10}$ & 0.545 & 0.507 & 8 & 7 & 6 & 6 \\
\hline Germany & $3.7 \cdot 10^{10}$ & 0.543 & 0.565 & 6 & 8 & 8 & 7 \\
\hline Sweden & $3.2 \cdot 10^{10}$ & 0.583 & 0.600 & 7 & 6 & 17 & 8 \\
\hline France & $2.8 \cdot 10^{10}$ & 0.491 & 0.568 & 9 & 13 & 10 & 9 \\
\hline Austria & $2.5 \cdot 10^{10}$ & 0.516 & 0.601 & 10 & 10 & 18 & 10 \\
\hline Greece & $2.3 \cdot 10^{10}$ & 0.449 & 0.481 & 11 & 14 & 4 & 11 \\
\hline Finland & $2.2 \cdot 10^{10}$ & 0.515 & 0.607 & 12 & 11 & 20 & 12 \\
\hline United Kingdom & $2.05 \cdot 10^{10}$ & 0.508 & 0.605 & 13 & 12 & 19 & 13 \\
\hline Luxembourg & $2.03 \cdot 10^{10}$ & 0.518 & 0.614 & 14 & 9 & 22 & 14 \\
\hline EU-27 & $1.8 \cdot 10^{10}$ & 0.409 & 0.567 & 15 & 16 & 9 & 15 \\
\hline Hungary & $1.7 \cdot 10^{10}$ & 0.417 & 0.580 & 16 & 15 & 13 & 16 \\
\hline Spain & $1.6 \cdot 10^{10}$ & 0.397 & 0.577 & 17 & 17 & 12 & 17 \\
\hline Czech Republic & $1.1 \cdot 10^{10}$ & 0.364 & 0.595 & 18 & 18 & 15 & 18 \\
\hline Poland & $4.6 \cdot 10^{9}$ & 0.299 & 0.591 & 19 & 20 & 14 & 19 \\
\hline Lithuania & $3.9 \cdot 10^{9}$ & 0.274 & 0.622 & 20 & 22 & 25 & 20 \\
\hline Romania & $3.8 \cdot 10^{9}$ & 0.246 & 0.600 & 21 & 27 & 16 & 21 \\
\hline Slovakia & $3.6 \cdot 10^{9}$ & 0.268 & 0.617 & 22 & 23 & 24 & 22 \\
\hline Slovenia & $3.1 \cdot 10^{9}$ & 0.260 & 0.570 & 24 & 24 & 11 & 23 \\
\hline Portugal & $3.4 \cdot 10^{9}$ & 0.251 & 0.616 & 23 & 26 & 23 & 24 \\
\hline Estonia & $2.9 \cdot 10^{9}$ & 0.282 & 0.638 & 25 & 21 & 27 & 25 \\
\hline Ireland & $2.7 \cdot 10^{9}$ & 0.309 & 0.647 & 26 & 19 & 28 & 26 \\
\hline Latvia & $2.3 \cdot 10^{9}$ & 0.255 & 0.632 & 27 & 25 & 26 & 27 \\
\hline Bulgaria & $1.8 \cdot 10^{9}$ & 0.216 & 0.609 & 28 & 28 & 21 & 28 \\
\hline
\end{tabular}

In order to efficiently apply DEA to ratio data, an output-oriented DEA model without inputs (Halkos, Salamouris, 2004) was employed. Consequently, the three ratios - net value added per AWU, crop output per hectare, and livestock output per LSU - were considered as outputs for DEA. Furthermore, the hypothetic inputs of 1 were defined for each DMU (i. e. Member State). The employed ISYDS / SIAD package (Angulo Meza et al., 2005) solved the CCR and BCC models defined by Eq. 5 and Eq. 6, respectively. Given the nature and variation of the analysed data set, both models yielded the same results. The scale efficiency, therefore, was not estimated. TE is depicted in Fig. 2.

As Fig. 2 suggests, there were four cases of efficient farming in 2008 among the EU Member States - in the Netherlands, Malta, Denmark, and Cyprus. It is worth noting that, Rimkuviene et al. (2010) also reported Malta and the Netherlands as states characterised by efficient farming. Indeed, only the Netherlands, Cyprus, and Denmark became peer DMUs for another 23, 19, and 5 states, respectively. The Netherlands were ranked as the most efficent state. Therefore, these states could be considered as examples of a successful agricultural policy in the EU. The peer weights are lambda coefficients in Eqs. 5 and 6. By analysing these coefficients one can reveal the theoretical prospective development path for a certain DMU. As for Lithuania, these peer states would be Cyprus and the Netherlands. Obviously, some managerial aspects of the Cyprian agricultural policy could be implemented in Lithuania. On the other hand, modernization of the Lithuanian agricultural sector could be mainly based on the Netherlandish experience. According to the efficiency scores, Lithuania and Latvia reached the efficiency of 52 and 54 per cent, whereas in Estonia and Poland it was of 58 per cent. Hence, the output indicators should be increased by respective margins in order to erradicate the radial inefficiency.

According to the results of DEA, Finland, Austria, Sweden, Germany, Luxembourg, Belgium, the United Kingdom, Hungary, Italy, France, and Czech Republic follow the aforementioned four states in the above order. The remaining states - Greece, Estonia, Poland, Latvia, Spain, Slovakia, Lithuania, Ireland, Portugal, Slovenia, Bulgaria, and Romania - were placed below the EU average. The mean TE for the old EU Member States (EU-15) was 75 per cent, whereas that for the new Member States (EU-12) accounted for 61.3 per cent, and the EU-27 average was 62.8 per cent. In 


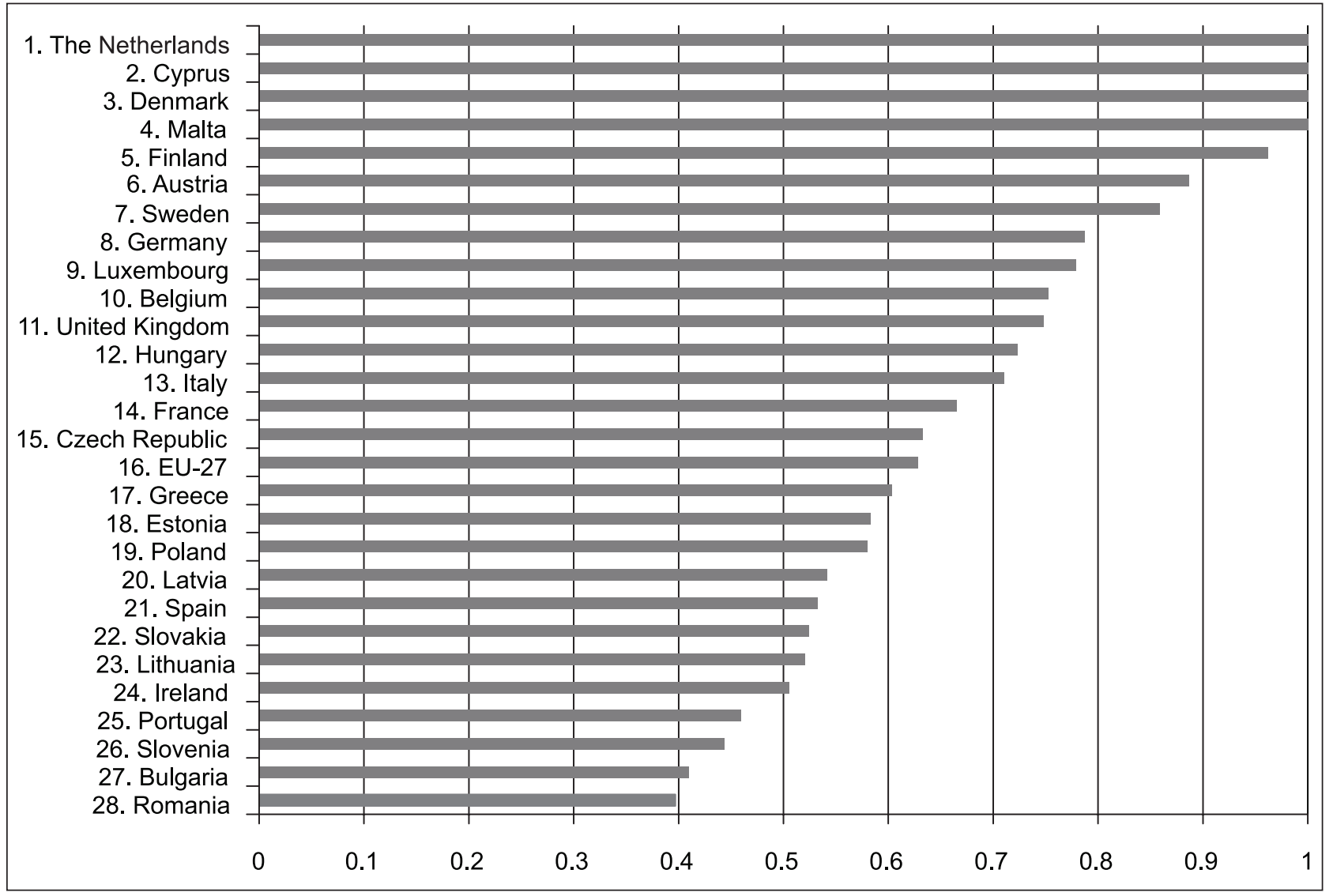

Fig. 2. Technical efficiency of farming in the EU Member States, 2008

this case, Estonia is attributed a higher rank as compared with Latvia and Estonia. Figure 3 shows the variation of ranks provided to certain EU Member States according to MULTIMOORA and DEA.

As Fig. 3 suggests, the ranks provided by both means of analysis are distributed along the diagonal line meaning an indentical rating. Moreover, the correlation coefficient $(\mathrm{R}=0.86)$ confirms these findings. Thus, it might be concluded that DEA and MULTIMOORA provide us with consistent rankings of the EU Member States with respect to their farming efficiency.

As mentioned before, the DEA enables to estimate the potential values of the variables under consideration. In case of the output-oriented DEA model, one can obtain respective output targets for each DMU. Achieving these targets would place the respective DMU on the efficiency frontier. Figures 4-6 present these results.

Considering the selected countries, the largest absolute slack in crop production per ha was estimated for Germany (Fig. 4): in order to reach the efficiency frontier, the German crop output should increase from 1.2 thousand up to 5.7 thousand EUR/ha, i. e. by the margin of five times (growth of over 420 per cent). Latvia, however, should achieve the largest increase in relative terms, i. e. crop output here should increase tenfold. As Fig. 4 suggests, the three Baltic States should reach a similar level of crop output, whereas Germany should seek for much higher values. At the other end of the spectrum, a lower level of crop output was estimated for Poland, albeit it should still meet the increase of some 120 per cent. Noteworthy, the Netherlands were depicted in Fig. 4 since this is a peer country. These differences were caused by respective bundles of outputs peculiar to each states. In our case, they are related to differences in agricultural production structures and productivity across the EU Member States.

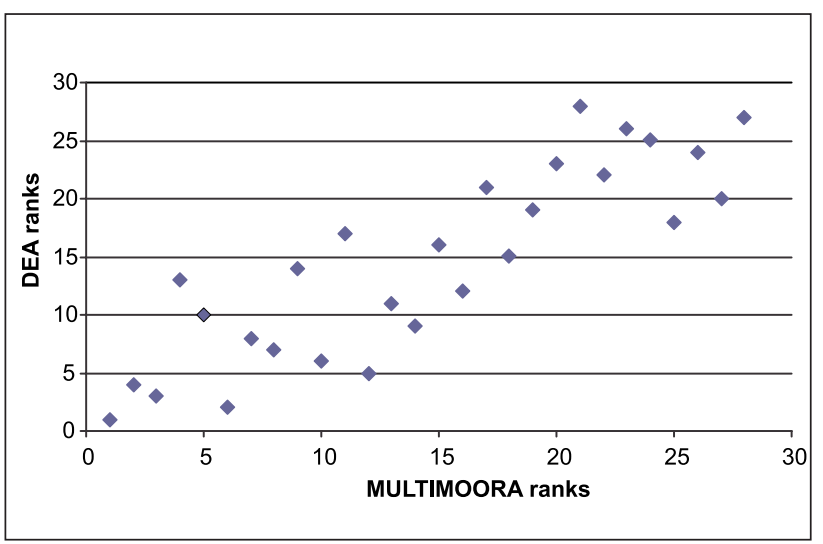

Fig. 3. The variation of ranks provided by DEA and MULTIMOORA for the EU Member States 


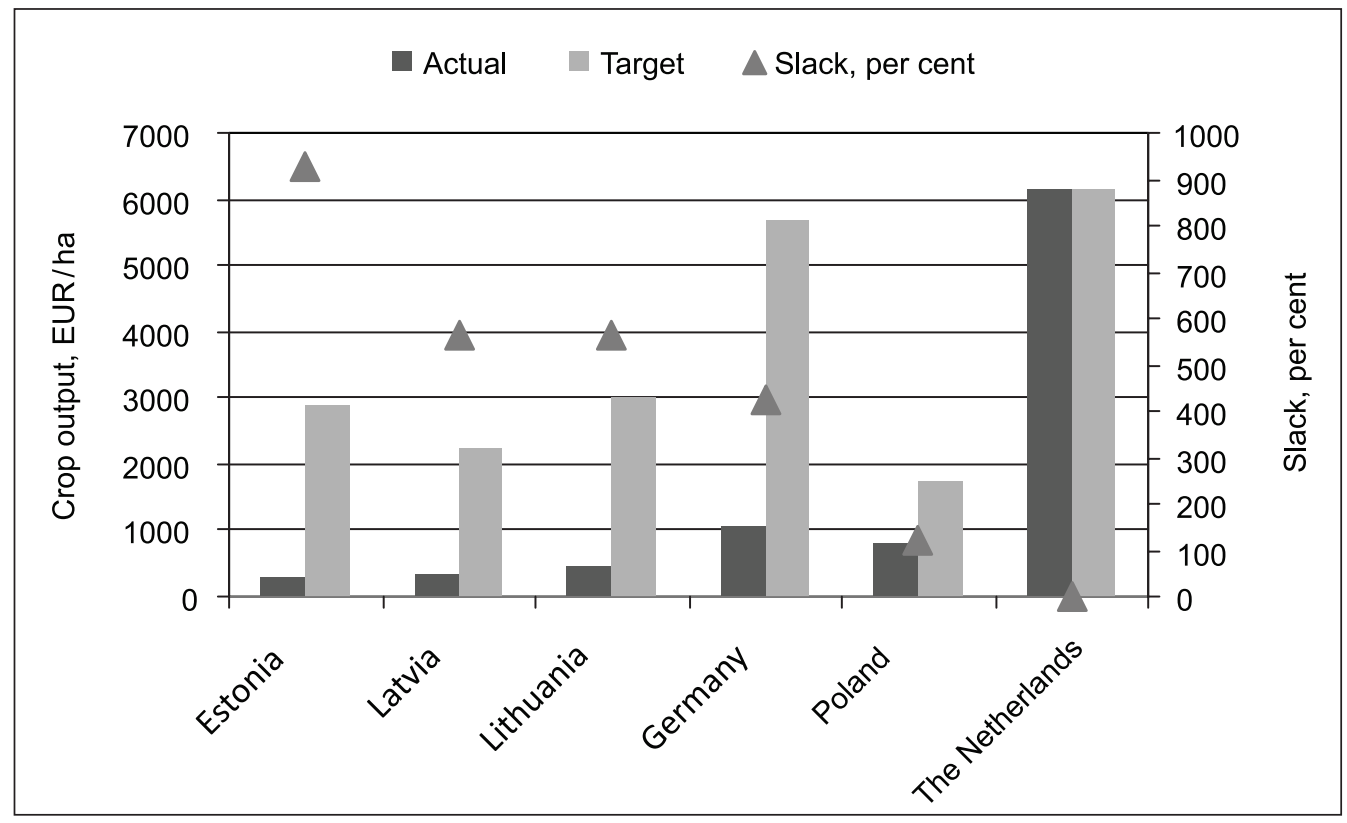

Fig. 4. Crop output targets and slacks for the selected EU Member States, 2008

Livestock output slacks are much lower for the selected states (Fig. 5). For instance, a target of 1761 EUR / LSU was estimated for Lithuania. However, Lithuania was attributed the relatively highest slack. Given the Netherlands is not the sole peer country influencing lisvestock output targets for the selected states, the three Baltic States were attributed the output targets higher than those of the former country. These findings suggest that the Baltic States have some competitive advantage in husbandry. However, the relatively low livestock intensity in these states prevents them from approaching the efficiency frontier.
The Baltic States and Poland are characterised by a relatively low labour productivity (Fig. 6). The slacks of net value added per AWU account for 72-92 per cent. Indeed, these states have relatively high numbers of persons employed in agriculture. Thus, the labour-intensive agriculture should be transformed into the capital-intensive one there.

The high value of slacks in crop otput (land productivity) and the net value added per AWU (labour productivity) in the three Baltic States indicate the necessity of qualitative and quantitative changes to be implemented here. More

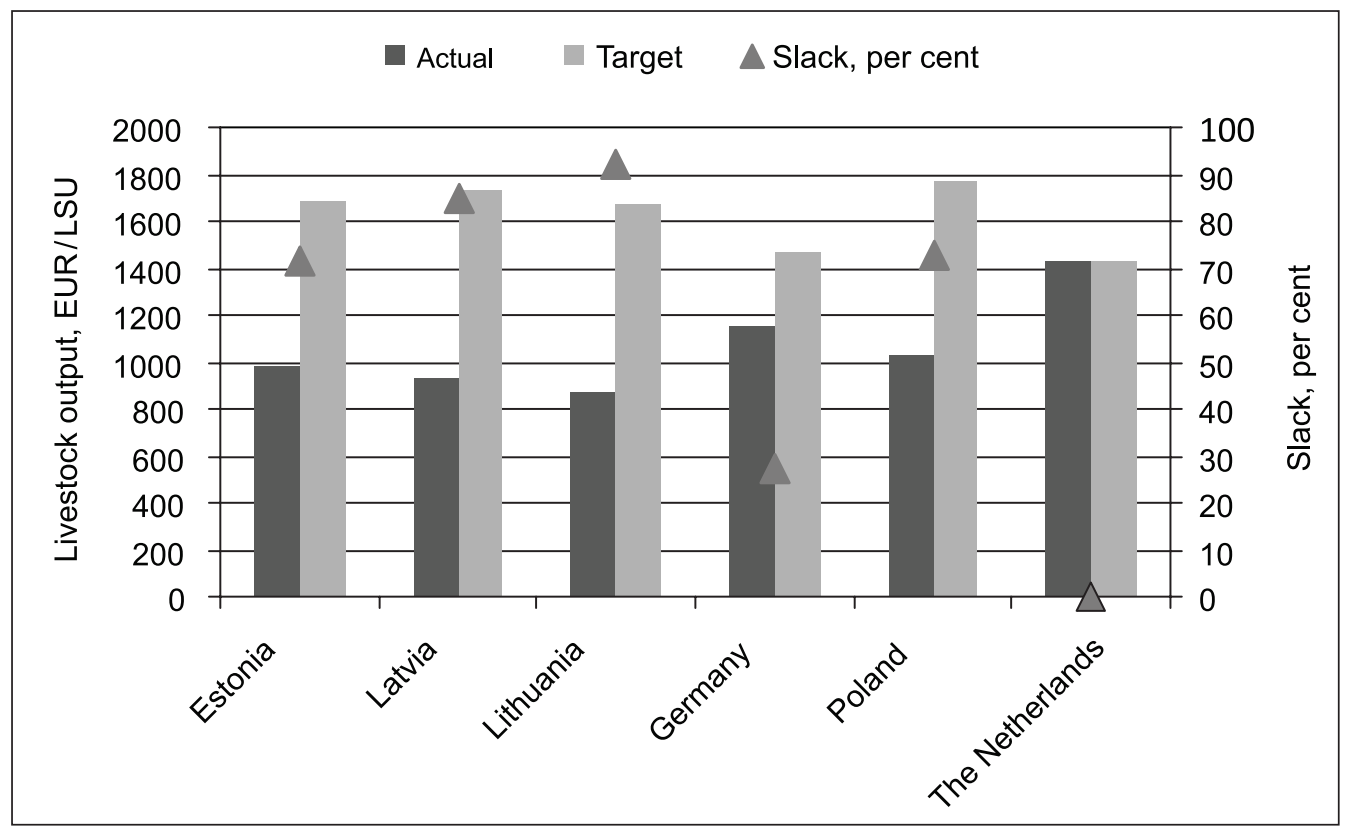

Fig. 5. Livestock output targets and slacks for selected EU Member States, 2008 


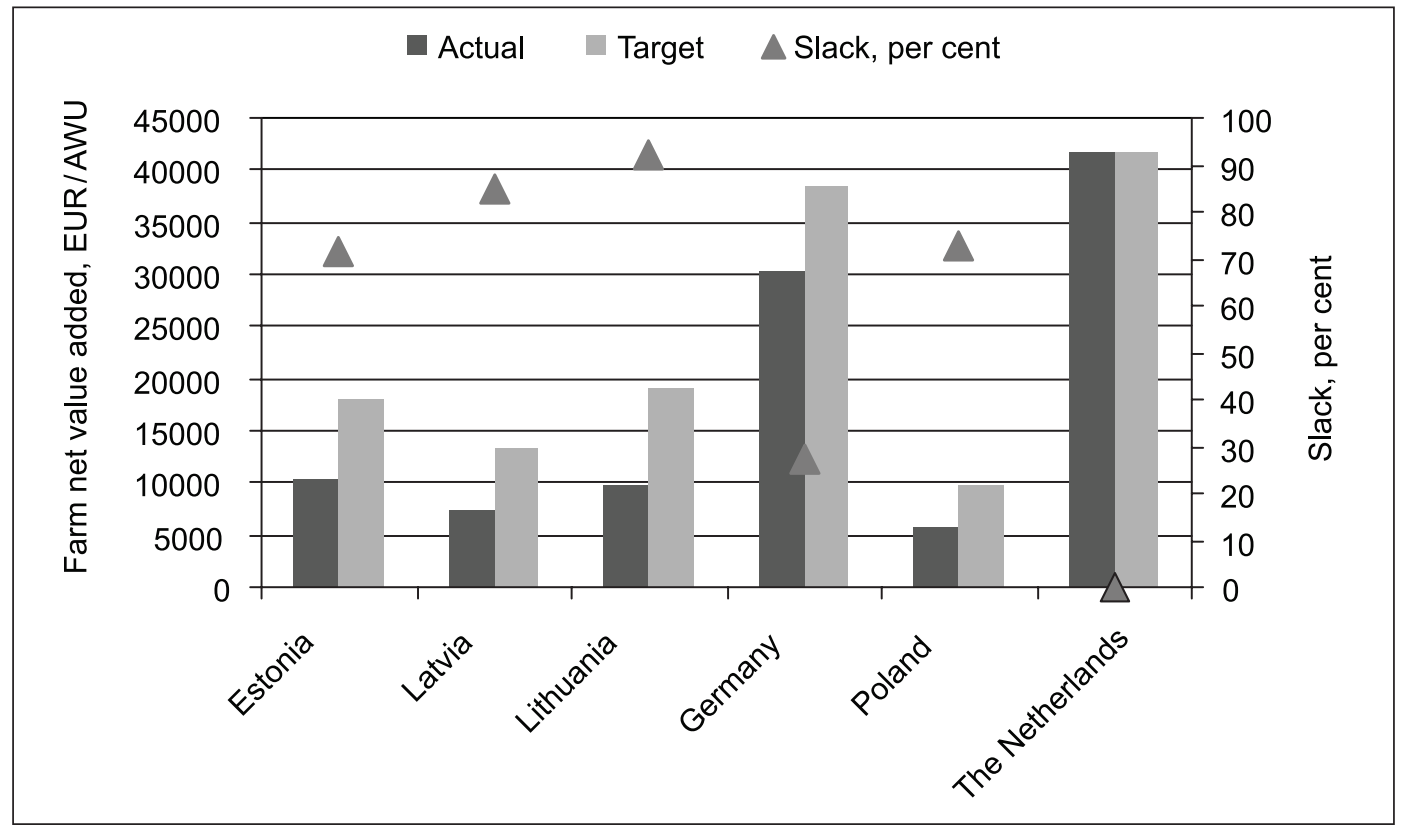

Fig. 6. Farm net value added targets and slacks for selected EU Member States, 2008

specifically, agricultural modernization should transform the current labour-intensive agricultural business into a more sophisticated one. Indeed, the value added generated in agriculture mainly relies on productivity which, in turn, could be fostered by employing the state of-the-art scientific knowledge and implementing innovative projects (Paunksnienè, Stalgienè, 2009).

Husbandry, nevertheless, remains the most efficient agricultural activity for these states. As Skurdeniene and Ribikauskas (2009) have argued, milk production and pig farming are the activities suitable for Lithuanian climatic conditions. The low value of the livestock density index in Lithuania, Latvia, and Estonia exhibits the possible intensification to be achieved.

It is the EU financial support that indirectly shapes business decisions taken by farmers. The EU support, such as CAP payments and structural funds, should be distributed with respect to the objectives defined by such scientific methods as DEA. For instance, analysis of output slacks suggests that investment support could be mainly directed towards the new EU Member States, thus promoting the modernization of their agrucultural sectors.

\section{CONCLUSIONS}

Farming efficiency was evaluated across the EU Member States on the basis of data from FADN by the MCDM method MULTIMOORA and DEA. The derived economic indicators, namely the ratios (the total crop output per ha, total livestock output per LSU, and net value added per AWU), were used as variables to evaluate farming efficiency instead of the typically used input-output variables. This choice led to the dimension reduction, which is an important feature of DEA. An output-oriented DEA model without inputs was therefore applied.

The EU Member States were ranked according to the indicator system by applying the MULTIMOORA method. The EU Member States were conditionally grouped into three groups encompassing high-, medium-, and low-performing states. The high-performance group comprised the Netherlands, Malta, Denmark, Italy, Belgium, Cyprus, Germany, Sweden, and France. The third group consisted of Lithuania, Romania, Slovakia, Slovenia, Portugal, Estonia, Ireland, Latvia, and Bulgaria.

The application of DEA enabled identifying the main factors of inefficiency as well as the way of prospective development. As Fig. 2 suggests, there were four examples of efficient farming in 2008 among the EU Member States, namely the Netherlands, Malta, Denmark, and Cyprus. Noteworthy, Rimkuviene et al. (2010) also reported Malta and the Netherlands as states characterised by efficient farming. Considering the number of cases when a certain state is a peer DMU for another state, the Netherlands were ranked as the most efficent state. According to the results of DEA, Finland, Austria, Sweden, Germany, Luxembourg, Belgium, the United Kingdom, Hungary, Italy, France, and Czech Republic followed the aforementioned four states exactly in this order.

According to the DEA efficiency scores, Lithuania and Latvia reached the efficiency of 52 and 54 per cent, whereas Estonia and Poland that of 58 per cent. Hence, the output indicators should be increased by respective margins in order to eradicate the radial inefficiency. A purely mathematical analysis suggests the Netherlands and Cyprus being the prospective examples for the Baltic States in the area of agricultural development. 
The high value of slacks in crop otput (land productivity) and the net value added per AWU (labour productivity) for the three Baltic States indicate the necessity of qualitative and quantitative changes to be implemented here. More specifically, agricultural modernization should transform the current labour-intensive agricultural business into a more sophisticated one. Husbandry, nevertheless, remains the prospective activity for the Baltic States. However, livestock intensity there should approach the sustainable level. The EU support in the form of CAP payments and structural funds should be distributed with respect to the objectives defined by such scientific methods as DEA.

Received 29 July 2011 Accepted 15 November 2011

\section{References}

1. Alvarez A., Arias C. 2004. Technical efficiency and farm size: a conditional analysis. Agricultural Economics. Vol. 30. P. 241-250.

2. Angulo Meza L., Biondi Neto L., Soares de Mello J. C. C. B. et al. 2005. ISYDS - Integrated System for Decision Support (SIAD - Sistema Integrado de apoio a Decisão): A software package for data envelopment analysis model. Pesquisa Operacional. Vol. 25(3). P. 493-503.

3. Baležentis A., Baležentis T. 2010. Europos Sąungos valstybių narių kaimo darnaus vystymo vertinimas. Management Theory and Studies for Rural Business and Infrastructure Development. Vol. 23(4). P. 16-24.

4. Baležentis A., Baležentis T. 2011a. Kaimo darnaus vystymo strateginis valdymas: daugiakriterinio vertinimo metodai ir integruotas Lietuvos ūkininkų ūkių veiklos efektyvumo vertinimas. Management Theory and Studies for Rural Business and Infrastructure Development. Vol. 25(1). P. 25-35.

5. Baležentis A., Baležentis T. 2011b. Framework of strategic management model for strategy Europe 2020: Diachronic analysis and proposed guidelines. Inžinerine ekonomikaEngineering Economics. Vol. 22(3). P. 271-283.

6. Banker R. D., Charnes A., Cooper W. W. 1984. Some models for estimating technical and scale inefficiencies in data envelopment analysis. Management Science. Vol. 30(9). P. 1078-1092.

7. Belton V., Stewart T. J. 2002. Multiple Criteria Decision Analysis: an Integrated Approach. Boston: Kluwer Academic Publications. $372 \mathrm{p}$.

8. Brauers W. K. M., Zavadskas E. K. 2006. The MOORA method and its application to privatization in a transition economy. Control and Cybernetics. Vol. 35(2). P. 445-469.

9. Brauers W. K. M., Zavadskas E. K. 2010a. Project management by MULTIMOORA as an instrument for transition economies. Technological and Economic Development of Economy. Vol. 16(1). P. 5-24.

10. Brauers W. K. M., Zavadskas E. K. 2010b. Robustness in the MULTIMOORA model: the example of Tanzania. Transformations in Business \& Economics. Vol. 9(3). P. 67-83.
11. Brauers W. K. M., Zavadskas E. K. 2011. MULTIMOORA optimization decides on a bank loan to buy property. Technological and Economic Development of Economy. Vol. 17(1). P. 174-188.

12. Charnes A., Cooper W. W., Rhodes E. 1978. Measuring the efficiency of decision-making units. European Journal of Operational Research. Vol. 2(6). P. 429-444.

13. Charnes A., Cooper W. W., Rhodes E. 1981. Evaluating program and managerial efficiency: an application of data envelopment analysis to program follow through. Management Science. Vol. 27(6). P. 668-697.

14. Coelli T. J., Prasada Rao D. S., O’Donnell C. J. et al. 2005. An Introduction to Efficiency and Productivity Analysis. Springer. $349 \mathrm{p}$.

15. Cooper W. W., Seiford L. M., Tone K. 2007. Data Envelopment Analysis: A Comprehensive Text with Models, Applications, References and DEA-Solver Software. Second edn. Springer. $490 \mathrm{p}$.

16. Debreu G. 1951. The coefficient of resource utilization. Econometrica. Vol. 19(3). P. 273-292.

17. Farrell M. J. 1957. The measurement of technical efficiency. Journal of the Royal Statistical Society. Series A, General. Vol. 120. Part 3. P. 253-281.

18. Gorton M., Davidova S. 2004. Farm productivity and efficiency in the CEE applicant countries: a synthesis of results. Agricultural Economics. Vol. 30. P. 1-16.

19. Halkos G.E., Salamouris D. S. 2004. Efficiency measurement of the Greek commercial banks with the use of financial ratios: a data envelopment analysis approach. Management Accounting Research. Vol. 15. P. 201-224.

20. Jaržemskienè I. 2009. Research into the methods of analysing the productivity indicators of transport terminals. Transport. Vol. 24(3). P. 192-199.

21. Kahraman C. 2008. Multi-criteria decision making methods and fuzzy sets. In: Kahraman C. (ed.). Fuzzy Multicriteria Decision Making. Springer. 591 p.

22. Kalirajan K. P., Shand R. T. 2002. Frontier production functions and technical efficiency measures. Journal of Economic Surveys. Vol. 13(2). P. 149-172.

23. Koopmans T. C. 1951. An analysis of production as an efficient combination of activities. In: Koopmans T. C. (ed.). Activity Analysis of Production and Allocation. Cowles Commission for Research in Economics. Monograph No. 13. New York: Wiley. 404 p.

24. Kriščiukaitienė I., Tamošaitienė A., Andrikienè S. 2007. Racionalaus dydžio ūkių modeliavimas. Žemès ūkio mokslai. T. 14. (Priedas). P. 78-85.

25. Kriščiukaitienė I., Andrikienè S., Galnaitytė A. ir kt. 2010a. Grūdų rinkos prognozès iki 2020 metų. Management Theory and Studies for Rural Business and Infrastructure Development. Vol. 23(4). P. 74-84.

26. Kriščiukaitienė I., Galnaitytė A., Andrikienè S. ir kt. $2010 \mathrm{~b}$. Gyvulininkystès sektoriaus prognozès iki 2020 metų. Management Theory and Studies for Rural Business and Infrastructure Development. Vol. 22(3). P. 76-86.

27. Odeck J. 2009. Statistical precision of DEA and Malmquist indices: A bootstrap application to Norwegian grain producers. Omega. Vol. 37(5). P. 1007-1017. 
28. Paunksnienè J., Stalgienè A. 2009. Pridètinès vertès augimą sąlygojantys veiksniai maisto ir gèrimų pramonèje. Žemés ükio mokslai. T. 16(1-2). P. 76-86.

29. Ramanathan R. 2003. An Introduction to Data Envelopment Analysis: A Tool for Performance Measurement. Sage Publications. 201 p.

30. Ray S. C. 2004. Data Envelopment Analysis: Theory and Techniques for Economics and Operations Research. Cambridge University Press. 353 p.

31. Rimkuvienė D., Laurinavičienė N., Laurinavičius J. 2010. ES šalių žemès ūkio efektyvumo ịvertinimas. L Ľ̌UU mokslo darbai. Nr. 87(40). P. 81-89.

32. Roy B. 1996. Multicriteria Methodology for Decision Aiding. Dordrecht: Kluwer. 292 p.

33. Skurdenienè I., Ribikauskas V. 2009. Kaimo plètros priemonių igyvendinimas ir inovatyvumo aspektai tradicines ir ekologinès gyvulininkystès kontekste. Žemès ūkio mokslai. T. 16. Nr. 3-4. P. 137-144.

34. Tamošaitienė A., Juškevičienẻ D., Kriščiukaitienè I. ir kt. 2010. Ūkininkų ūkių verslo stabilumo vertinimas naudojant finansinès analizès santykinius rodiklius. Management Theory and Studies for Rural Business and Infrastructure Development. Vol. 5(24). P. 173-185.

35. Vinciūnienè V., Rauluškevičienè J. 2009. Lietuvos respondentinių ūkininkų ūkių techninio ir masto efektyvumo neparametrinis vertinimas. LŽŪU mokslo darbai. Nr. 85(38). P. 39-46.

36. Zavadskas E. K., Turskis Z. 2011. Multiple-criteria decision-making (MCDM) methods in economics: an overview. Technological and Economic Development of Economy. Vol. 17(2). P. 397-427.
Tomas Baležentis, Alvydas Baležentis

\section{DAUGIAKRITERINIS ŪKININKAVIMO SANTYKINIO EFEKTYVUMO VERTINIMAS EUROPOS SĄJUNGOS VALSTYBĖSE NARE்SE}

Santrauka

Ekonominio sektoriaus veiklos efektyvumo vertinimas yra svarbus priimant strateginio valdymo sprendimus ịvairiuose valdymo lygmenyse. Šio tyrimo tikslas - pasiūlyti naują ūkininkavimo efektyvumo daugiakriterinio vertinimo ir palyginimo modelį. Tikslui pasiekti taikyti: statistinè analizè, daugiakriterinio vertinimo metodas MULTIMOORA, duomenų apgaubties analizè. Ūkininkavimo efektyvumui ịvertinti visose Europos Sajungos (ES) valstybėse narèse remiantis ūkių apskaitos duomenų tinklo duomenimis taikyta daugiakriterinio vertinimo rodiklių sistema, apimanti tris santykinius rodiklius, kurie apibūdina šešis sąnaudų ir produkcijos rodiklius. Ūkininkavimo ES valstybèse narèse efektyvumas buvo ịvertintas pagal minètą rodiklių sistemą taikant MULTIMOORA metodą. Tyrime ypač daug dèmesio skiriama Baltijos valstybèms ir panašiomis geopolitinèmis bei ekonominėmis sąlygomis veikiančiai Lenkijai. Tyrimo rezultatai rodo, kad 2008 m. šių valstybių ūkiai veikè santykinai neefektyviai, palyginti su vidutiniais ES rezultatais. Duomenų apgaubties analizè leido nustatyti potencialius efektyvumo didinimo būdus. Baltijos valstybėms svarbiausia padidinti augalininkystés produkcijos apimtis ir ekonominįžemės ūkio produktyvumą. Straipsnyje pateikiami žemès ūkio plètros ateities iššūkiai Baltijos valstybėse.

Raktažodžiai: ūkininkavimo efektyvumas, daugiakriterinis sprendimų prièmimas, duomenų apgaubties analizè, strateginis valdymas 